\title{
CONSTITUTIONAL ORDER IN MULTI-ETHNIC SOCIETIES
}

\section{Yash Ghai}

One of the most interesting issues in constitutional theory today concerns the political organisation of multi-ethnic societies. A key question is the extent to which ethnic identity should be recognised in public as opposed to private life.

A major criticism directed at the liberal democratic is that, in its preoccupation with individual rights, it refuses to acknowledge ethnic differences. It is argued that under the cloak of individualism, the values and mores of the dominant community are imposed on minorities, whether of gender, religion or culture.

The response to this criticism in places like Bosnia, Kosovo, Estonia and Hungary is the constitutional recognition of cultural groups through separate representation in the legislature and the executive, and special cultural or educational institutions.

Fiji's experience of recent weeks shows the difficulty of organising the system of government in multi-ethnic societies. As in other colonies, Britain ruled Fiji through a policy of dividing the people into ethnic groups.

The separation of races went beyond the political to embrace educational, health and even economic institutions. Most colonies repudiated this principle when they became independent, in the pursuit of national identity and unity.

Fiji, however, did not do so, in large part because by then Indo-Fijians outnumbered the indigenous Fijians and the latter were afraid that a common electoral roll based on universal franchise in a Westminstertype system would reduce them to the status of a political minority. 
With the active encouragement of the British, the indigenous leaders chose a system of communal voting that would guarantee them a parliamentary majority. The 1970 independence Constitution did ensure uninterrupted political hegemony for 17 years. The hegemony was reinforced by a strong ideology of traditionalism and chiefly order, in which high chiefs occupied positions of great economic and social privilege, in the manner of feudal lords.

The ideology emphasised the unity of the indigenous community, and habits of obedience by the commoners to the chiefs. Britain had established institutions, including the Great Council of Chiefs, and an ethnic Fijian army, to reinforce this sense of oneness. The entrenchment of Fijian land rights and the inalienability of land to non-indigenous persons had the same effect.

All this was done to preserve the 'traditional' system in the face of rapid economic and social changes. It severely hampered the ability of indigenous people to enter the modern economy by discouraging the enterprise of commoners and by social rules which valued collective property above individual possessions.

The chiefs became a kind of rentier class, living on rents paid by IndoFijian farmers or foreign hoteliers to whom indigenous land was leased. It is not surprising that this system came under heavy stress as indigenous Fijians were drawn into the monetary economy, principally as workers. More importantly, commoners obtained access to education and became increasingly resentful of their inferior position in the traditional hierarchy.

The system would have collapsed a long time ago had it not been for the presence of Indo-Fijians, who were placed in the role of the 'other', presented by chiefs as threatening the integrity and hegemony of the indigenous people $-a$ theme the British had astutely used in the colonial period to divide the two communities.

Nevertheless fissures within the indigenous community by the 1980 s allowed a predominantly Indo-Fijian coalition with some Fijian support to win the general elections of 1987 and form the government, led by an indigenous Fijian Prime Minister. 
This government was overthrown within a month by an army officer, a commoner, with the active connivance of high chiefs. The new administration introduced a Constitution in 1990 which attempted to ensure a permanent indigenous parliamentary majority by increasing the number of seats for indigenous people and reserving key state offices to indigenous persons. Many other privileges were established for them.

The theory behind this Constitution was that of political order through the hegemony of one group over others, just like the white supremacy espoused by the National Party in South Africa and the Jews in Israel in their dominance over Arabs.

The consequences of this Constitution were disastrous: rampant corruption, decline in economic growth, outflow of talent and capital, and a general sense of alienation. Divisions within the indigenous community sharpened as the Indo-Fijians were sidelined.

In the mid-1990s there was increasing realisation that Fiji's political stability and economic progress depended on a constitutional order that was fair to all its communities, protected everyone's human rights, and was based on a national consensus.

These attitudes facilitated a constitution oriented towards ethnic integration, through non-ethnic seats in addition to ethnic representation, an electoral system which placed a premium on appealing to voters of all communities, and a system of executive power sharing, rejecting the exclusiveness embedded in earlier Constitutions.

The early experience of the 1997 Constitution, which also provided extensive protection of individual and collective rights of indigenous people, was favourable. Ethnic tensions decreased, ethnic-based parties began to integrate or co-operate across old divides, and even the appointment of an Indo-Fijian Prime Minister, with a truly non-racial government, was accepted without much fuss.

Once again, certain elements within the indigenous Fijians, sidelined after the elections, embarked on a coup. But this time the real impulses were not the displacement of Indo-Fijians, but competition for power within indigenous communities. As that storm-trooper, George Speight, 
has gone about his business, divisions within the indigenous Fijians have surfaced for all the world to see.

It was clear in 1987 that the chiefs were being used in narrow partisan ways, to lend legitimacy to a usurpation of power. It was equally clear that in the long run this would politicise their role, drawn as they would be increasingly into intra-Fijian quarrels.

The logic of that development has been well exposed by Speight's opportunism combined with his cynicism. If he has managed to bring many indigenous people together in his anti-Indo-Fijian tirades, his constant refrain that the 'real enemy' are Indians highlights the fragility of his coalition.

He has pitted high chiefs against high chiefs, the Great Council of Chiefs against the ethnic Fijian army, one confederacy against another. He, a commoner, has torn to shreds the ideology of traditionalism - all in the name of communal unity and hegemony. One of the many lessons that one can draw from this saga is that the modern preoccupation with 'identity' and 'difference' as building blocks of political orders needs to be approached with caution.

It is grist to the mill of opportunists and hate-mongers (as if the former Yugoslavia had not already taught us that lesson).

It fragments communities and denies our common humanity. Instead we should pay more attention to the framework of human rights which remind us of our common predicament and promise. 